\title{
Editorial Afterword
}

\author{
Graham Holderness
}

This is the second issue of Critical Survey dedicated to Arab Shakespeare. When I invited Margaret Litvin to edit the first, which appeared in 2007, the field hardly existed. ${ }^{1}$ Ten years ago in 2006 the World Shakespeare Congress in Brisbane hosted a panel on Arab Shakespeare that began to shape a new field of inquiry. Prior to that event, there was no academic complement to the rich and continuous engagement between Shakespeare and Arab dramatists, translators and performers that had been going on at least since the nineteenth century. As Margaret pointed out in Critical Survey:

The Arab world went unnoticed in the numerous edited volumes on international Shakespeare reception and appropriation. Though often aware of the major congresses on the subject, Arab scholars were rarely represented there. The World Shakespeare Bibliography Online, which catalogues materials in 118 languages, has had only one active Arabicspeaking contributor in the past decade. Interesting studies of Shakespeare reception written in Arabic have not been translated. In English, a handful of articles and dissertations has represented the field. When scholars in Europe and the United States have occasionally mentioned 'Arab Shakespeare' to their colleagues, they have presented it almost as a novelty. ${ }^{2}$

All this has changed, as this issue - based on a panel held at the World Shakespeare Congress 2016 in London - abundantly testifies.

People ask me how I 'got into' Arab Shakespeare, since I am not an Arabist. But I didn't need to be. My first encounter with Arab Shakespeare was in Hammersmith in West London, very close to where I live; and it was in English. I am talking of course about Sulayman Al-Bassam's The Al-Hamlet Summit, performed at the Riverside Studios, Hammersmith, in March 2004. I didn't have to go looking very far for Arab Shakespeare, as it was already, in Al- 
Bassam's hands, a globalized initiative capable of reaching out to an Englishman, in his own language - the Summit was turned into Arabic at a later stage. As I described it in a study of 'Shakespeare and Globalisation' published in 2006:

The Al-Hamlet Summit is a representative product of multicultural communication in a global frame. It occupies one of innumerable sites that have no territorial linkage, yet reflect on global events ... This is the ultimate globalisation of Shakespeare, since it implies an infinite multiplicity of local/global Shakespeares. ${ }^{3}$

We hear a lot more about local/global Shakespeares now than we did when that was written in 2004.

On the basis of this work, I got in touch with Sulayman Al-Bassam, and entered into what I think is a fairly unique form of collaboration between a dramatist and an academic studying his work, a kind of cross-disciplinary cultural conversation. The first product of that rapprochement was a bilingual edition of The Al-Hamlet Summit, published by University of Hertfordshire Press. ${ }^{4}$ The play was presented there in both English and Arabic texts, with photos and production details, and with critical commentary by both editor and dramatist.

The Al-Hamlet Summit then went on a successful world tour, involving performances in Bath, Cairo, Kuwait, Elsinore and Singapore. The relationship of collaboration between academic and dramatic creativity then went much further, as I became involved in Sulayman's next project, his adaptation of Richard III, commissioned by the RSC - talking to the writer as he was in the process of creating the work, receiving successive drafts and commenting on them, feeding critical ideas into the creative process. The play was initially titled Baghdad Richard, and took the form of an agitprop work focused explicitly on Saddam Hussein. I don't think it is any exaggeration to claim that the collaboration of academics such as myself and Margaret Litvin helped to move it towards a play with broader political and cultural horizons. It was of course premiered at the Royal Shakespeare Theatre, Stratford in 2007, as Richard III: An Arab Tragedy, and subsequently toured during 2008-9 in Washington DC, Abu Dhabi, New York, Kuwait, Damascus, Athens, Paris and Amsterdam. As it went round the world it was also translated into different national languages, as the Arabic script was surtitled in the local tongue. ${ }^{5}$ When the play was performed at Peter Brook's theatre 
in Paris, the script's French translation was published together with critical essays translated into French. ${ }^{6}$ During that world tour, we were able to present the research underpinning the adaptation at conferences for academics and theatre professionals, sometimes with Sulayman and sometimes not, including at Shakespeare's Globe and the British Shakespeare Association's Fourth Annual Conference (both 2009).

This interplay of critical research and creative practice was repeated for Speaker's Progress, Al- Bassam's adaptation of Twelfth Night. Staged in 2011 and 2012 in New York, Boston, Kuwait, Beirut, Tunisia, Cairo and Amsterdam, Al-Bassam publicly acknowledged during its Boston run that his decision to select Twelfth Night as his source text was informed by my essay 'Rudely Interrupted', a 2007 study of the suicide bombing of the Doha Players theatre during a production of Twelfth Night. ${ }^{7}$ Following the world tour of The Speaker's Progress, Sulayman and I collaborated to publish an English-language text of the whole series of plays as The Arab Shakespeare Trilogy (Al-Hamlet Summit, Richard III, Speaker's Progress), published by Bloomsbury/Methuen Drama in 2014. ${ }^{8}$

So what we have in Sulayman Al-Bassam's work is a cultural example of some interest to the theme of the World Shakespeare Congress 2016, 'Creating and Re-creating Shakespeare'. As academics, we haven't just been positioned as observers of an artistic process, or critics of a finished product. We have actually been directly involved in the creative process, not of course as co-authors, but as contributors, as collaborators, as creative partners. This crossdisciplinary engagement has been made possible only because the dramatist himself has been willing to let us in, and has proved enormously receptive to critiques of his work, and responsive to the infusion of new ideas. As a model of cultural practice, it allows us to reconfigure the normal positions of creative practice and intellectual commentary, since both are entailed in the collaboration. Artists can become more critical, and critics more creative. 


\section{Notes}

1. Critical Survey 19, no. 3, Arab Shakespeare (December 2007), edited by Margaret Litvin.

2. 'Editorial,' Margaret Litvin, Critical Survey 19, no. 3 (December 2007): 1-2.

3. 'Arabesque: Shakespeare and Globalisation' (with Bryan Loughrey), in Globalisation and Its Discontents: Writing the Global Culture, ed. Stan Smith, Essays and Studies (Cambridge, UK: D.S. Brewer, 2006), 43.

4. Suleyman Al-Bassam, The Al-Hamlet Summit (Hatfield: University of Hertfordshire Press, 2006), 9-19.

5. See my 'From Summit to Tragedy: Sulayman Al-Bassam's Richard III and Political Theatre', Critical Survey 19, no. 3 (December 2007): 106-25, and "'Silence Bleeds": Shakespeare across Borders. The Shakespearean Adaptations of Sulayman Al-Bassam', European Journal of English Studies 12, no. 1, New Englishes (Spring 2008): 59-77.

6. E.g. my 'Shakespeare entre 1'Orient et l'Occident', in Sulayman Al-Bassam, Richard III: une tragedie arabe (Paris: L'avant-scene Theatre, 2008), 66-68.

7. “'Rudely Interrupted”: Shakespeare and Terrorism' (with Bryan Loughrey), Critical Survey 19, no. 3 (December 2007): 126-42.

8. Sulayman Al-Bassam, The Arab Shakespeare Trilogy (London: Bloomsbury, 2014). 